The authors reported no conflicts of interest.

The Journal policy requires editors and reviewers to disclose conflicts of interest and to decline handling or reviewing manuscripts for which they may have a conflict of interest. The editors and reviewers of this article have no conflicts of interest.

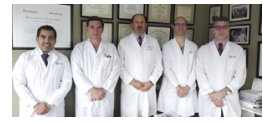

\section{BILATERAL INTERNAL THORACIC ARTERY GRAFTING IN ELDERLY PATIENTS MAKES}

\section{SENSE INDEED}

\section{To the Editor:}

We thank Sun and colleagues for their important comments on our recent article. As we stated, we adopted bilateral internal thoracic artery (BITA) grafting in elderly patients in our routine practice in 2003 in more than $95 \%$ of our patients with multivessel coronary artery disease and focused on the therapeutic influence of this approach in patients older than age 70 years in our report. ${ }^{1}$ We are fully aware that the length of the study period could have influenced the final results; however, that would be the expected evolution of a department trying to provide and adapt the best therapeutic approach in coronary surgery over time.

The limitation of our study-its Achilles heel-is the observational design and retrospective nature of our protocol due to the influence of unmeasured confounders. We used 2 different statistical methods to adjust for preoperative imbalances (ie, propensity score matching and multivariate Cox regression) in an effort to account for all measurable confounders, but the bias produced by unmeasured confounders may persist. After adjusting for measurable confounders, the use of BITA grafting had beneficial effects on survival in patients aged 70 years and older. These results are consistent with several authors who reported the benefits of BITA grafting even in older patients. $^{2}$

Randomized trials provide the most powerful form of clinical evidence; however, selection bias and crossover from 1 therapeutic arm to the other always occurs over time. Despite its great contribution, the Arterial Revascularization Trial was a disappointment to many so-called artery advocates: $36 \%$ of the patients enrolled did not receive the assigned treatment (crossover), and $22 \%$ of the patients in the single internal thoracic artery group received a second arterial graft in the form of a radial-artery graft, which could explain the lack of statistically significant results at 10 years. $^{3}$

Furthermore, the Arterial Revascularization Trial had no power to analyze subgroups because its sample size was calculated for 10-year mortality in the entire cohort. Our study, after rigorous matching, ended up with a group of 486 patients older than age 70 years, which is representative for a reliable retrospective analysis.

Finally, coronary artery bypass grafting $(\mathrm{CABG})$ is still a strong and valid therapeutic option due to its efficacy in the treatment of coronary artery disease. As surgeons, we are in charge of potentiating its beneficial effects and, at the same time, turning it to a simpler procedure. Off-pump CABG can be performed by any surgeon despite being more technically demanding. Off-pump CABG using BITA grafting could be an ideal therapeutic option, with fewer postoperative events and better long-term survival; it also a more patient-friendly procedure: fewer skin incisions, extubation in the operating room, shorter hospital length of stay, and faster return to a normal life. Go for it!

\section{Daniel Navia, $M D$ \\ Juan Espinoza, $M D$ \\ Mariano Vrancic, $M D$ \\ Fernando Piccinini, $M D$ \\ Mariano Camporrotondo, MD \\ Department of Cardiac Surgery \\ ICBA Instituto Cardiovascular \\ Buenos Aires, Argentina}

\section{References}

1. Navia D, Espinoza J, Vrancic M, Piccinini F, Camporrotondo M, Dorsa A, et al. Bilateral internal thoracic artery grafting in elderly patients: any benefit in survival? J Thorac Cardiovasc Surg. October 3, 2020 [Epub ahead of print].

2. Pettinari M, Sergeant P, Meuris B. Bilateral internal thoracic artery grafting increases long- term survival in elderly patients. Eur J Cardiothorac Surg. 2015;47:703-9.

3. Taggart DP, Benedetto U, Gerry S, Altman DG, Gray AM, Lees B, et al. Bilateral versus single internal-thoracic- artery grafts at 10 years. N Engl J Med. 2019;380:437-46.

\section{https://doi.org/10.1016/j.jtcvs.2020.12.093}

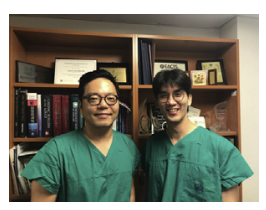

\section{REPLY: PURSUING THE EXCELLENCE, SHARING THE STANDARD \\ Reply to the Editor:}

We are grateful for the opportunity to have constructive discussions with Navia and colleagues ${ }^{1}$ on an interesting and important issue in the field of coronary surgery. We believe that such debates and discussions have always nourished the body of knowledge in our cardiovascular surgery community. Navia and colleagues ${ }^{1}$ reported a comparative result between bilateral and single internal thoracic artery uses in patients aged 70 years or older. We value the authors' efforts; they utilized the best available methods to address the selection biases in their institutional retrospective data, but still with uncorrectable confounders.

Despite many agreeable points in the report by Navia and colleagues, ${ }^{2}$ we would like to point out several aspects with 
The authors reported no conflicts of interest.

The Journal policy requires editors and reviewers to disclose conflicts of interest and to decline handling or reviewing manuscripts for which they may have a conflict of interest. The editors and reviewers of this article have no conflicts of interest. which we respectfully, disagree. First, off-pump coronary arterial bypass grafting (CABG) may be a great tool for expert surgeons as surgeries without cardiopulmonary bypass definitely offer several advantages. A number of authors have demonstrated excellent off-pump CABG outcomes by experienced hands; however, this does not mean that such good results are generalizable to average cardiac surgeons or to the real-world practice where variations in the level of surgical performances do exist among surgeons and institutions. Leading professionals are always responsible for pioneering and exploring the cutting edge of their field; however, as physicians, practice guidelines should best reflect the current atmosphere. Currently available evidence does not seem to support superiority of off-pump CABG compared with conventional $\mathrm{CABG}$ even through a large-scale randomized trial conducted by expert CABG surgeons. ${ }^{3}$ Therefore, the author's arguments may be confined to their institutional experience in this regard. Secondly, although the authors argue that the Arterial Revascularization Trial (ART) has no power to analyze subgroups due to its limited sample size, its sample size of the subgroup aged $\geq 70$ years is nearly twice as large as that of the author's study. ${ }^{4}$ Even considering all the limitations of ART raised by the authors, ART is still the best evidence to date and has shown equivalent outcomes between bilateral and single internal thoracic artery procedures in this patient group. Navia and colleagues $^{1}$ deserve respect for all their efforts as leading-edge surgeons in the field of CABG. Such efforts should be encouraged even more to develop ideal strategies in coronary revascularization therapy; however, general acceptance of their results in daily common practice should be viewed in a balanced sense.

Sung Jun Park, $M D$

Joon Bum Kim, MD, PhD

Department of Thoracic and Cardiovascular Surgery

Asan Medical Center

University of Ulsan College of Medicine

Seoul, South Korea

\section{References}

1. Navia D, Espinoza J, Vrancic M, Piccinini F, Camporrotondo M, Dorsa A, et al. Bilateral internal thoracic artery grafting in elderly patients: any benefit in survival? J Thorac Cardiovasc Surg. October 3, 2020 [Epub ahead of print].
2. Navia D, Espinoza J, Vrancic M, Piccinini F, Camporrotondo M. Commentary: bilateral internal thoracic artery grafting in elderly patients makes sense indeed. J Thorac Cardiovasc Surg. October 3, 2020 [Epub ahead of print].

3. Lamy A, Devereaux PJ, Prabhakaran D, Taggart DP, Hu S, Straka Z, et al. Fiveyear outcomes after off-pump or on-pump coronary-artery bypass grafting. $N$ Engl J Med. 2016;375:2359-68.

4. Taggart DP, Benedetto U, Gerry S, Altman DG, Gray AM, Lees B, et al. Bilateral versus single internal-thoracic-artery grafts at 10 years. N Engl J Med. 2019;380:437-46.

https://doi.org/10.1016/j.jtcvs.2020.12.101

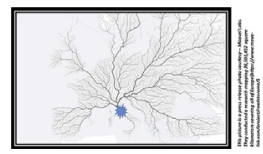

\section{REPLY: MĪLLE VIAE DÜCUNT HOMINĒS PER SAECULA RÖMAM}

\section{Reply to the Editor:}

I read with great interest the author's letter based on their article reporting exemplary outcomes using bilateral internal thoracic arteries among elderly patients receiving coronary artery bypass grafting. "Mīlle viae dūcunt hominēs per saecula Rōmam" translated from the Latin means "a thousand roads lead men forever to Rome." This phrase likely refers to the "Millarium Aureum," a monument erected by the Emperor Caesar Augustus in central Rome. However, proverbially, it translates to the idea that there are many acceptable ways to reach the same goal. $^{2}$

I believe that all physicians work toward a common aim: providing the best possible care for their patients. Yet how they achieve that common endpoint often depends on individual skill, circumstance, and environment. Expanding indications for transcatheter therapies have led to a decline in open surgical procedures. ${ }^{3}$ Hospital reimbursements for procedures continue to decline. Surgeons often receive a very small fraction of the reimbursed amount ${ }^{4}$ but are subject to careful external scrutiny. ${ }^{5}$ In this highly complex world, each physician must carve his or her own path toward the common goal.

Yet, as Navia and colleagues correctly proclaim, I too recommend that we go for it!

Salil V. Deo, $M D$ Surgical Services Louis Stokes Cleveland VA Medical Center Northeast Ohio VA Healthcare System Cleveland, Ohio

\section{References}

1. Navia D, Vrancic M, Piccinini F, Camporrotondo M. Bilateral internal thoracic artery grafting in elderly patients makes sense indeed. J Thorac Cardiovasc Surg. 2022;164:e88.

2. Dictionary CE. The Cambridge English Dictionary. Accessed December 29, 2020 Available at: https://dictionary.cambridge.org/us/dictionary/english/all-roadslead-to-rome

3. US Food and Drug Administration. FDA expands indication for several transcath eter heart valves to patients at low risk for death or major complications associated with open-heart surgery; 2019. Accessed December 29, 2020. Available at: https:// 